Linguistik Terapan 17 (1) (2020): 8-16

Jurnal Linguistik Terapan Pascasarjana

Available online

http://jurnal.unimed.ac.id/2020/index.php/JLT-Unimed

\title{
Developing English Speaking Material through \\ Contextual Teaching and Learning (CTL) \\ for Beauty Study Program
}

\author{
Nilam Ulami Siregar \\ I Wayan Dirgeyasa \\ Rahmad Husein
}

English Applied Linguistics Program

Postgraduate Program-Universitas Negeri Medan

Diterima Desember 2020; Disetujui Februari 2020; Dipublikasikan April 2020

\section{ABSTRACT}

The research was aimed to identify the target needs and learning needs of the tenth grade student of Beauty Study program at SMK Pariwisata Imelda Medan and to develop English speaking material through CTL for Beauty Study Program. This research was implemented by conducting Research and Development (R n D) study by Borg and Gall. There are four steps were done namely: (1) need analysis; (2) developing material; (3) evaluating and (final revision). The target clients of this research were 34 people which consisted of (a) 30 students of Tenth grade of Beauty Program chosen by total random sampling technique; (b) English lectures; (c) English teacher; and (d) stakeholder. There were 3 types of technique for collecting the data applied in this research, they were questionnaire which used to gain the need analysis and validate the material, documentation consisted of the existing material, and interview to support the data gained from the previous techniques. The data of the research was analyzed descriptively. The result of this research were (1) the students needed the English speaking material which contains the material relating to their filed expertise and supported by innovative and creative learning process, and (2) the English speaking material developed through CTL is a set of English speaking material which consisted of 6 units.

Keywords: R and D, Speaking Material, Beauty Study, CTL

How to Cite: Siregar, Nilam Ulami (2020). Developing English Speaking Material through Contextual Teaching and Learning for Beuaty Study Program. Jurnal Linguistik Terapan Pascasarjana Unimed, 17 (1): 8-16.

ISSN 0216-5139 


\section{INTRODUCTION}

The specific purpose of vocational school are (1) to prepare students to become productive human resources, able to work independently, to fill vacancies that exist as a middle level manpower in accordance with competence in the skills program chosen, (2) to prepare students to be able to choose a career, tenacious and persistent in competent, adaptable working environment and develop a professional attitude are interested in, (3) provide students with science, technology, and art to be able to develop themselves in the future independently or through education higher and (4) to prepare learners with competencies in accordance with the selected expertise program.

Beauty study program is one of branch from expertise program which exists in vocational high school. This program attracts the students' attention because the students who graduate will have some skills and able to open their own business such as opening business of beauty salon, skin care and etc. Thus the graduates of this program should have some advantages in order they will be ready to compete with the current market demand. Therefore improving the students skill are not only concerned with the expertise itself but also it should be balanced with the subject that could support their career level, for example to gain the employment industry in the world that requires a few things such as mastering English language related to their skill. Moreover having English proficiency of their expertise will give a big advantage for the graduates of Beauty Study program.

In fact, English ability of Beauty Study program students of Imelda Vocational high school is relatively low especially for speaking skill. It was expressed by the Headmaster, he conveyed that the speaking skill ability of the students is very poor.

Rini (2017) is an English teacher of Imelda Vocational High School stated that the English book for Beauty Study Program is not available. Thus, the students cannot get any knowledge of English relates to their expertise especially for the speaking skill. Regarding this phenomenon, some decision must be taken relate to designing and developing English Speaking Material for Beauty Study Program in order it could be a good reference for the students of Beauty Study program in learning English of their occupational.

One prominent research comes from Dirgayasa on developing English writing learning material through a Genre Based Approach shows that teaching and learning process done by the lecturer still far from the students' need. The teaching strategies used by the lecturer were not optimal, the writing materials were still not relevant and unadequate because the material used is for general. 
Furthermore, there are some issues to decide on choosing the appropriate strategy, one of them is employing different topics and various activities in the classroom in order to motivate student to be an active learner.

CTL is an approach of teaching and learning that helps the teacher to relate subject materials to the real world situationsand motivates the student to make connection between knowledge and its application to their daily life.

"CTL is an educational process that aims to help student see meaning in the academic material they are studying by connecting academic subject with the context of their daily lives, that is with the context of their personal, social and cultural-circumtance. To achieve this aim, system encompasses the following eight components: making meaningful connection, doing significant work, self-regulating learning, collaborating, critical and creative thinking, nurturing the individual, reaching high standarts, and using authentic assessment [4].”

In implementing Contextual Teaching and Learning concepts, we have to consider the basic principle before we use it in the teaching process. As stated by Ditjen Dikdasmen there are seven principles of Contextual Teaching and Learning process. Constructivism is the main foundation in Contextual Teaching and Learning concept [5]. It emphasizes on the construction of the learners ${ }^{e e}$ understanding which is done actively, creatively, and productively not only based on their knowledge and their previous knowledge but also from their meaningful learning experiences. The second principle is questioning. Contextual Teaching and Learning encourages student to understand something by relating their real life concept to the material. Teacher has some roles to make sure that students develop their thinking capability. One of the roles is by questioning the students to find out the information they have already understood. The next is inquiry. It means the learning process is based on a search and discovery through a process of thinking in a systematic way. Then, Learning Community in CTL, learning can be done through study groups. Students are divided into groups whose members are heterogeneous. The teachers might combine slow and fast learners. Another principle is modeling. It is an example to demonstrate something that can be imitated by every student. For example, the teacher gives examples of how to pronounce an English word. Reflection is a process of straightening out the experience that has been learned by re-organizing events or events that have gone through the learning. Through reflection on learning experiences, that will be included in students' cognitive structure that will eventually become part of the knowledge that has been formed, the last is authentic 
assessment is the process where the teachers gather information about the students learning progress. This assessment is needed to determine whether students are actually learning or not. It is whether the knowledge of student has its positive impact to both intellectual and mental development in their lives. The results obtained from the application of CTL in teaching English speaking, it was effective for several reasons. First, CTL encouraged the students to be self-motivated learners [6].

In CTL, the students used their individual skills, interests, and cultural backgrounds to build their own knowledge which led them to discover meaning in the study of English rather than something elaborated by the teacher. Another result of the research on contextual teaching and learning approach was done by Rafida [7]. The result shows that contextual teaching and learning gives students a chance to be active in the teaching-learning process. It allows students to experience a more meaningful and real learning. By engaging students in some group works helps students to improve their soft skill in cooperating and socializing with other people. They also can learn how to solve a problem. The activities engaged in contextual teaching and learning make learning more productive.

Due to all aspect stated above, the writer would like to conduct a research on how the students' need of speaking material and how English speaking materials through Contextual Teaching and Learning developed for Beauty Study Program at vocational school

\section{METHODOLOGY}

The research design which will be conducted in this research is a research development (R\&D) design proposed by Borg and Gall [8]. Due to the objectives of this research is education, the research is called Educational Research Development (E-RD). There are four steps should be run in this research namely Phase 1. Evaluation and Need Analysis, Phase 2. Development and Designing the Learning Material, Phase 3. Validating the Learning Materials. Phase 4. Final Revision.

The research design could be seen in the following figure. 


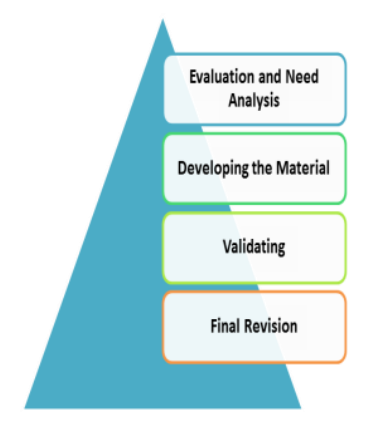

Figure 1. Research Design

The source of data of this study will be 29 correspondents namely: a) 25 student of Beauty Study Program grade tenth 2017/2018, b) English teacher, they were taken by using total sampling technique, c) Stakeholder, they will be taken by using random sampling technique and d) 2 English Lecturer. While the data of the study will be the evaluation of the document sheet, the accumulation of questionnaires, and the utterances from the interview sheets.

The data will be collected by documentary sheet, questionnaires, and in depth in interview. Documentary sheet which will be used to collect data dealing with the students' record, teacher's record, and other related document. Documentary sheet will be used to gain the data such as the existing material, assessment type, learning strategies, and the students' achievement. Questionnaires consists of a number of statements and questions in form of Likert scale. They will be given to the students and English lectures as experts. The questionnaires will be administered to the students to collect the data dealing with the learners' learning needs and to the experts to validate the new learning material. Interview sheet was used to collect the data from respondents orally. It will be applied to English teacher, students, and the stakeholder, the data was used to support from the previous instrument documentation sheets and questionnaires.

The technique for analyzing the data of the research is descriptive technique. The data gained will be described particularly.

\section{FINDINGS AND DISCUSSION}

The analysis of target needs was viewed at three aspects, namely necessities, lacks, and wants. Based on the results of needs analysis, the students mainly needed to be able to understand and perform dialogues/conversations, texts, news and English songs" (70\%), speak English in English class (76\%), ask and answer questions in the classroom (while 
listening to the teacher's presentation or explanation) (45\%) and communicate in English with foreigners $(80 \%)$.

In relation to the students'lacks, they considered that their English grammar is low (34\%). In relation to the students' wants, they want to have specific education theme relating to their expertise in each learning speaking $(70 \%)$. they expect the specific theme will help them later in their work field.

\section{The Description of the Learning Needs}

In the results of the needs analysis, the students learning needs were found in the items which are categorized as input, activities (including the participants'roles), and setting.

In terms of the input, the students preferred asking and answering questions in the classroom (while listening to the teacher's presentation or explanation) (65\%), having their expertise theme in speaking activity (60\%) and having pictures, video, flash card, and songs as the media for their speaking activity $(70 \%)$.

Most of the students needed various activities in learning speaking English. In terms of activities, the students preferred having brainstorming, or ice breaking before starting the activity, having various games in speaking activity (60\%), having role playing and practice dialogues (51\%), having teacher correction (65\%), speaking and expressing their thought and ideas in English in order to speak English fluently (43\%), matching English words with provided words in learning vocabulary (55\%), having oral presentation (50\%), group discussion $(60 \%)$. In relation to the setting, the students preferred doing tasks or learning activities in pairs or group $(72 \%)$.

\section{Results of Development}

After conducting the needs analysis, the speaking material was developed. It was developed based on the results of the needs analysis and still on the grid of K-13 curriculum syllabus. The speaking material for beauty study program of this research was developed through CTL. The material was developed by considering the principle of CTL. Each unit will adopting the principle, such as inquiry, learning community, reflection, etc.

There are six chapters developed in this research. The concerning task input can be concluded as the inputs which are comprehensible to the students. The comprehensible input will facilitate the students to learn and utilize their knowledge on the language and its use in the daily life. This is supported by Krashen's input hypothesis that states "We acquire 
languages when we understand messages (input) in the target language that are just a little beyond our current level of acquired competence [8]. In order for learners to progress from one stage of acquisition to the next, they need to comprehend language that includes a structure at the stage beyond that of the current level". The students will fail to acquire the target language if the inputs are not understood by them. When the inputs are too difficult to be understood, the students will reluctant to learn the language because they feel hard in learning it. On the other hand, when the inputs are too easy for them, they will reluctant to learn the language because actually they need a challenge to improve their current level of acquired competence. The appropriate inputs should contain themes that are interesting and familiar for the students. This finding was supported by Tomlinson's review on the materials development by some experts. Tomlinson states that based on the research studies in materials developments, many local materials do provide comprehensible connections to the culture of the learners [9]. Walker in his study also finds that the one of features that can make the lesson difficult is the unfamiliar situations [10]. In other words, even when teaching something difficult, the lesson can be fun if an interesting topic is selected for the students. The interesting themes will motivate them to learn the target language, while uninteresting themes will make them reluctant to learn. Themes that are used in these tasks are themes that are related to the students expert field and chosen by themselves. The pictures which are presented in the tasks also appropriate since the pictures are interesting and they help the students to understand the information. In relation to task procedure, the appropriate activities are put in the same sequence for all units: warming up activities, main teaching and learning activities, and the reflection activity. The activities also sequenced gradually, from the easiest task to the most difficult ones. The gradual sequencing will motivate the students to learn the target language. Unit title in the materials was taken from one of the expressions used in the unit or the main discussion of the unit. The title reflects the topic that was chosen by the learners before in the needs analysis process. The input was organized based on the topic and basic competencies. Each task has an input. The input for speaking tasks are dialogues, text, pictures, video, and games.

Each unit consists of several tasks covering speaking, pronunciation, vocabulary, and grammar skills. The organization of each unit consists of three parts, namely the warm up part, the main teaching and learning part, and the reflection part. The warm up part consists of a unit title and an brainstorming section. The unit title is related to the basic competence for every unit. Beneath the unit title, there is an overview paragraph that explains the learning 
objectives. The main teaching and learning part consists of some tasks in term of discussion. pairs work, vocabulary, or presentation. Then the reflection task consists of an overview of the learning objectives.

\section{CONCLUSION}

Based on the research findings, the conclusions can be drawn as follows. In terms of the learning needs, the students also like to have a specific speaking material relates to their expertise. They also need various activities and settings in practicing the language. Then based on the students' need the material for speaking developed through contextual teaching and learning. The material developed consists of some organization. The organization of each unit consists of three parts, namely the warm up part, main teaching and learning part, and reflection. The warm up part consists of a unit title and an ice breaking relates to the themes. Beneath the unit title, there is an overview paragraph that explains the learning objectives. The main teaching was developed based on the principle of CTL. thus, the main teaching for each unit has different activities such as group task, pairs work, presentation, discussion and etc. The last part is reflection. The reflection unit was developed in order the students could cross check their achievement, whether the learning objectives achieve.

\section{REFERENCES}

Annisa, S. 2015. Teaching Speaking in English Using Contextual Teaching and Learning. English Education Journal (EEJ), 6(4).

Depdiknas, Kurikulum 2004; Standar Kompetensi Mata Pelajaran Bahasa Inggris Sekolah Menengah Pertama dan Madrasah Tsanawiyah. Jakarta, Pusat Kurikulum, Balitbang Depdiknas, 2004.

Dirgayasa, I W. 2014. The Development of English Writing Learning through a Genre Based Approach for English Department at University. SELT

Gall, M \& Borg, W. 2003. Educational Research: An Introduction (7th ed.). New York: Longman.

Johnson, E. B. 2002. Contextual Teaching and Learning. Thousand Oaks: Corwin Press

Kakande, M., and Kaue, S. 2015. Teaching Strategies Used by Thai EFL Lecturers to Teach Argumentative Writing. Elsevier

Krashen, S.D. 1982. Principles and Practice in Second Language Acquisitions. Pergamon Press Inc. 
Rafida, T. 2016. Observing Contextual Teaching and Learning on Students' Achievement in Writing Recount Text. International Journal of English Language Teaching Vol.4,No.9, pp.57-68, November 2016.

Tomlinson, B. 1998. Materials Development in Language Teaching. Cambridge: Cambridge University Press.

Undang-Undang Sistem Pendidikan Nasional Tahun 2003. 